\title{
Why There Has Been an Increase in Cardiovascular Disease Mortality in Young People Over the Past Decade in the USA: Unrecognized Roles of Alcoholism, Drug Abuse, Illegal Migrants and Hypomagnesemia
}

\author{
Burton M Altura ${ }^{1-7 *}$ and Bella T Altura ${ }^{1,3-7}$ \\ ${ }^{1}$ Department of Physiology and Pharmacology, USA \\ ${ }^{2}$ Department of Medicine, USA \\ ${ }^{3}$ The Center for Cardiovascular and Muscle Research, USA \\ ${ }^{4}$ The School for Graduate Studies in Molecular and Cellular Science, The State University of New York, USA \\ ${ }^{5}$ Bio-Defense Systems, Ind, Rockville Centre, USA \\ ${ }^{6}$ Orient Biomedical, Estero, USA \\ ${ }^{7}$ Magnesium for Health Foundation, Patterson, USA
}

*Corresponding author: Burton M Altura, Department of Medicine, SUNY Downstate Medical Center, Brooklyn, New York, USA.

To Cite This Article: Burton M Altura, Why There Has Been an Increase in Cardiovascular Disease Mortality in Young People Over the Past Decade in the USA: Unrecognized Roles of Alcoholism, Drug Abuse, Illegal Migrants and Hypomagnesemia . Am J Biomed Sci \& Res. 2020 - 6(6). AJBSR. MS.ID.001087. DOI: 10.34297/AJBSR.2020.06.001087.

Received: 盋 December 14, 2019 ; Published: 眥 January 08, 2020

\section{Editorial}

Over the past decade, according to recent CDC mortality statistics, there is a growing number of cardiovascular deaths in the USA among young people (i.e. 16-55 years in age) [1]. This turn of events, among the younger people, is being attributed to obesity, type 2 diabetes, suicide, and bad diets, whereas the elderly population, i.e. those over age 70, appear to be living into their 90 's. Several well- known supposedly, healthy Broadway and Hollywood actors below age 55 (e.g., Luke Perry, Brittany Murphy, Heather O'Rourke, Alex Haley, among others) died of heart attacks/cardiac arrest recently [1]. Among these deaths, in the younger people, there appear to be deaths caused by strokes, although a number have been attributed to congestive heart failure. All three, namely heart attacks, strokes and congestive heart failure, among men younger than 55 years of age, are unusual, despite many of these subjects being-on statins and high-blood pressure medications with normal or only slightly elevated triglyceride and cholesterol levels [1].

Unless there is a suspicion of "foul-play", none of these deaths are ever autopsied or are blood samples taken for toxicology analyses. Since the third leading cause of death, after cancer in the USA, today appears to be overdose from alcohol, cocaine, amphetamines, and fentanyl-heroin combinations or polydrug use (mixed with marijuana) [2-4], we believe many of the deaths in the younger people today are a direct result of substance abuse superimposed upon obesity, type 2 diabetes, and poor diets. Today, alcohol is still the leading abused drug, in the world.

Analyses of blood samples taken from numerous subjects who were admitted into the ERs in our hospitals, after falls or battering, often indicated elevated blood levels of alcohol, cocaine, psychedelics, amphetamines, marijuana, and/or fentanyl-heroin [2-4].

Hypomagnesemia Found in Subjects Ingesting Alcohol and Substances of Abuse: An Underlying Potential Relationship to Heart Disease and Strokes

Random laboratory studies of young people (i.e., 30-55 years of age) admitted to the ERs in our hospitals, after falls, car accidents and/or battering, demonstrated ionized hypomagnesemia in most of these subjects [2-4], as ascertained with specially-designed electrodes which accurately measures ionized magnesium (Mg2+) [7-11]. Many of these subjects, on careful serum drug analysis, were found 
to exhibit elevated levels of alcohol, various psychedelic drugs, cocaine, amphetamines, heroin-fentanyl and/or marijuana [2-4] unpublished studies. Several recent studies, including our own, demonstrate that many heart attack victims, subjects with myocardial infarctions, congestive heart failure and/or strokes exhibit similar reduced serum levels of $\mathrm{Mg} 2+$ when looked for [7-20]. We do not believe these findings are mere coincidences. In addition, it is important to point out that drug addiction is now known to make such subjects very susceptible to multiple infectious diseases [21] which perforce would drive these young people towards high risks for MIs, CHF, strokes and SCD.

Is Obesity, Type 2 Diabetes and Poor Diet Major Causes of Heart Attacks, Cardiovascular Diseases and Strokes in The Observed Increases in Morbidity and Mortality Recently Being Observed in Young People?

Although it seems now clear that obesity, Type 2 diabetes, suicide, and poor diet are contributing factors to the recently observed increases in morbidity and mortality in young people, it must be stated that many of these victims often present with near-normal blood levels of lipids and are on statins and blood pressure medications [1]. Moreover, most of the victims we have observed coming to our ERs were not obese [unpublished findings] but nevertheless exhibited ionized hypomagnesemia together with elevated blood levels of alcohol and the substances of abuse.

$\mathrm{Mg}$ is essential for all carbohydrate, protein, lipid, and nucleic acid metabolism, and cell membrane structures and functions, including regulation of cardiac functions, vasomotor tone, capillary blood flows and nutrition, brain synaptic functions, brain metabolism and oxygenation [11,18,22]. Deficiency of Mg will cause disruption in all these bodily functions, unless proper daily intake of $\mathrm{Mg}$ is sustained [11,18,22].

Why Ionized Hypomagnesemia Can Cause Increased Morbidity and Mortality: Relationship to DNA Damage, Cellular Oxidation and Genotoxicity

Does hypomagnesemia frequently contribute to Myocardial Ischemia (MI), Congestive Heart Failure (CHF), strokes and Sudden Cardiac Death (SCD)? Will increased dietary intake of Mg lower the risk of ischemic heart disease (IHD) and strokes? Does Mg have a therapeutic value in preventing IHD, MI, CHF and SCD? All these questions are critical in determining whether our hypothesis has any validity.

Our studies on experimental animals, isolated blood vessels, human subjects, and vascular smooth muscle and endothelial cells in primary cell cultures have provided considerable insights into these important questions. Our work dating back to 1970 [22-29] has provided important information on this topic and has stimulated numerous clinical trials around the globe that support roles for increased dietary $\mathrm{Mg}$ in both the prevention/amelioration of IHD, MI, SCD, and strokes as well as the use of Mg therapeutically [30-36]. Experimental studies on numerous mammalian species demonstrate that hypomagnesemia can produce coronary and cerebrovascular arterial and arteriolar vasoconstriction, decreased capillary blood flows, inflammations, atherogenesis, increased vascular reactivity, and release of cytokines and chemokines resulting in continuous coronary and cerebrovascular vasospasms, and, over a period of time, atherosclerosis, IHD, MI, strokes and SCD $[2,11,18,35,36]$. This evidence demonstrates that $\mathrm{Mg}$ supplementation reduces ischemic events and that an increase in dietary intake would reduce the incidences of atherosclerosis, inflammations, coronary diseases, cerebrovascular diseases and improve the quality of life $[11,18,22]$.

Examination of the sera of approximately 35 cardiac patients with Prinzmetal-variant angina [8], 105 stroke patients [25], and over 150 patients with diverse substances of abuse brought into our ERs [2-4], unpublished findings, and using specificallydesigned electrodes for measurement of serum ionized Mg levels [7-11] revealed that, on average, there was a 35-45\% decrease in the ionized Mg. Measurement of interleukin 1a, TNF-alpha, and c-reactive protein indicated a strong correlation $(r=<0.001)$ to the serum ionized Mg level $[37,38]$ unpublished findings.

Extensive laboratory studies, performed by our group, on CV tissues and cells from animals fed daily diets low in Mg intake has clearly shown that these excised CV tissues and cells demonstrate considerable membrane damage, formation of reactive oxygen species (ROS), fragmentation of DNA and oxidation of DNA [1719,35-48], all of which would perforce induce potential alterations in cell integrity, cell functions and alterations in cell phenotypes. We have termed such a state "genotoxicity" [48]. Genotoxins are, thus, mutagens $[49,50]$. The result of genotoxins induces modifications in gene expression. We, thus, believe that dietary deficiency in Mg intake will result in chromosomal abberations which would produce early deaths from MIs, CHF, IHD, and/or strokes.

\section{Young Cancer Patients Given Chemotherapeutic Drugs and/or Radiation and Subjects Taking Proton -Pump Inhibitors Exhibit Severely Decreased Serum Levels of $\mathrm{Mg}$}

Interestingly, we and others have found that young cancer patients taking diverse chemotherapeutic agents and/or given radiation treatments exhibit $35-45 \%$ reductions in serum ionized Mg levels and demonstrate coronary insufficiency and/or cerebrovascular insufficiency and die of MIs, strokes, CHF, or SCD [51]. The exact numbers of these subjects appear to be increasing due to better laboratory analyses. Recently, it has been reported by several groups that patients taking proton-pump inhibitors often exhibit decreases in serum Mg coupled to cardiac problems [52]. 
Growing Numbers of Illegal Migrants Who are Infected with Deadly Diseases and Underfed Could be Expected to Present with Mg Deficiencies: Probable Relation to Increased Morbidity and Mortality Among Native-born Young Citizens and Legal Residents

Currently, Western societies are under a clear assault from the migration of undocumented illegal people, many of whom are young men, who are bringing, in many cases, contagious diseases that were eliminated in their countries until very recently (e.g., last 10 years) [53]. This migration of diseased individuals to the USA and elsewhere has overwhelmed the healthcare systems, infected thousands of people and their children, and cost millions of dollars per year. It has been suggested that such a situation, with people carrying deadly pathogens will increase susceptibility for citizens for development of several types of cardiovascular diseases (i.e., IHD, CHF, strokes and SCD) [54]. Although actual careful laboratory studies have not yet, to our knowledge, examined illegal migrants for their ionized Mg levels, we would be surprised if their serum levels were not, on average reduced more than $50 \%$.

\section{Conclusions and Future Thoughts}

Over the past decade, there has been an unexpected rise in the number of cardiovascular disease (CV) deaths in young people (i.e., 16-55 years of age) in the USA. Epidemiologists and physicians have speculated that this increased number of CV deaths is due to obesity, diabetes type 2 , and poor diets, despite the fact that most of the victims were taking statin drugs, anti-diabetic drugs, lipid-lowering medications and/or high- blood pressure loweringmedications. In contrast to these CV deaths, among the young, people over the age of 70 appear to be living longer than a decade ago which presents somewhat of a paradox. We and others have found that many of the younger people exhibit low serum levels of ionized Mg. Many young patients brought into our ERs, who experienced falls, battering, or car accidents exhibit sera containing numerous substances of abuse, which we have reported to cause reductions in cardiac, vascular, and brain levels of ionized $\mathrm{Mg}$. Low levels of Mg2 + have been found to be associated with higher risks for CV diseases, including MIs, CHF, stokes and SCD. Young cancer patients treated with numerous chemotherapeutic drugs exhibit low ionized Mg levels and increased risks for CV diseases, including MIs, CHF, strokes and SCD. Added to these risk factors, we must take into consideration the huge numbers of illegal adults and children who have been admitted into the USA over the past 10 years, who are carrying multiple deadly diseases (e.g., tuberculosis, measles, and plagues, among many others) which are known to be high- risk factors for development of $\mathrm{CV}$ diseases. It is our belief that the numerous risk factors enumerated in the present report, when taken together with obesity, type 2 diabetes and poor diets among the young can explain most of the increased number of $\mathrm{CV}$ deaths seen in young people in the USA over the past ten years.
Increased dietary intake of $\mathrm{Mg}$ should be very helpful in reducing $\mathrm{CV}$ morbidity and mortality in the younger population when taken together with proper medical care and nutrition of the migrants coming into the USA.

\section{Acknowledgements}

Most of our original studies, elucidated in the present report, were funded, in part, by research grants from the National Institutes of Health (i.e., The National Heart, Lung and Blood Institute; The National Mental Health Institute; The National Institute on Drug Abuse; and The National Institute on Alcoholism and Alcohol Abuse). In addition, numerous pharmaceutical companies awarded us non-restricted research grants (i.e., CIBA-GEIGY Pharmaceuticals; Sandoz Pharmaceuticals; The UpJohn Co., Pfizer Pharmaceuticals; and Warner Lambert Pharmaceuticals). We were fortunate to collaborate with numerous outstanding scientists and physicians who helped to make our studies successful, including Professor Solomon G. Hershey, Professor Lawrence M. Resnick, Professor Raj K. Gupta, Professor Adele B. Kostellow, Professor Gene A. Morrill, Professor Q.F. Huang, Professor J. F. Li, Dr. Aimin Zhang, Dr. Tao Zheng, Dr. Wenyan Li, Dr. Nilank C. Shah, Asefa Gebrewold, Anthony Carella, and Dr. Zhi-W. Yang.

\section{References}

1. McKay B (2019) Heart disease roaring back. Wall Street Journal 273(145): 1

2. Altura BM, Gebrewold A, Carella A, Shah Nc, Altura BT (2018) Stroke: A real danger from the therapeutic use of psychedelic drugs and the role of magnesium. EC Pharmacol \& Toxicol S1.01: 18-23.

3. Altura BM, Gebrewold A, Carella A, Shah NC, Shah GJ, Altura BT (2019) Stroke, headaches and hallucinations: real dangers of the recreational use of amphetamines and Ecstasy-like drugs: Unrecognized roles of hypomagnesemia. EC Pharmacol \& Toxicol 7 (7): 646-652.

4. Altura BM, Carella A, Gebrewold A, Shah NC, Shah GJ, Altura BT (2019) Why there is an increased number of deaths from heroin mixed with fentanyl in the USA: Potential roles of unrecognized hypomagnesemia and elevated levels of ceramides and platelet-activating factor particularly in brain stem area and potential relationship to euphoria and hallucinations. AS Pharmaceutical Sciences Journal 3(8): 55-62.

5. Brunton L, Knollman B, Hilal-Dandan R (2017) Goodman and Gilman's The Pharmacological Basis of Therapeutics, 13th Edn, McGraw-Hill Professional Publishers, New York.

6. Maisto SA (2018) Drug Use and Abuse. Wadsworth Publishing, New York.

7. Altura BT, Altura BM (1992) A new method for the rapid determination of ionized $\mathrm{Mg} 2+$ in whole blood, serum and plasma. Methods and Findings in Exp \& Clin Pharmacol 14(4): 297-304.

8. Altura BT, Altura BM (1991) Measurement of ionized magnesium in whole blood, plasma and serum with a new ion-selective electrode in healthy and diseased human subjects. Magnesium Trace Elem 10(2-4): 90-98.

9. Altura BT, Shirey TL, Young CC, Dell'Orfano K, Altura BM, et al. (1994) Characterization and studies of a new ion-selective electrode for free extracellular magnesium ions in whole blood, plasma and serum. In: Electrolytes, Blood Gases and Other Critical analytes: The Patient, the Measurement, and the Government, vol.14, Electrolytes Blood Gas Division AACC, ed by D'Orazio P, Burritt MF, Sena SF. Omni Press, 217: 152-173. 
10. Altura BT, Shirey TL, Young CC, Dell'Orfano K, Hiti J, et al. (1994) Characterization of a new ion selective electrode for ionized magnesium in whole blood, plasma, serum and aqueous samples. Scand J Clin Lab Invest 54(217): 21-36.

11. Altura BM, Altura BT (2016) Importance of ionized magnesium measurements in physiology and medicine and the need for ion-selective electrodes. J Clin Case Studies 1(2).

12. Whang R (1987) Magnesium deficiency: Pathogenesis, prevalence and clinical implications. Am J Med 82(3A): 24-29.

13. Salem M, Muiz R, Chernow B (1991) Hypomagnesemia in critical illness, A common and critically important problem. Crit Care J 7: 225-252.

14. Resnick LM, Altura BT, Gupta RK, Alderman MH, Altura BM, et al. (1993) Intracellular and extracellular magnesium depletion in type 2 (noninsulin-dependent) diabetes mellitus. Diabetologia 36(8): 767-770.

15. Markell MS, AlturaBT, Sarn Y, Delano BG, Hudo o, et al. (1993) Deficiency of serum ionized magnesium in patients receiving hemodialysis or peritoneal dialysis. ASAIO J 39: M801-M804.

16. Mauskop A, Altura BT, Cracco RQ Altura BM (1993) Deficiency in serum ionized magnesium but not total magnesium in patients with migraines: Possible role of Ca2+/Mg2+ ratio. Headache 33(3): 135-138.

17. Altura BM, Altura BT (1994) Role of magnesium and calcium in alcoholinduced hypertension and strokes as probed by in vivo television microscopy, optical spectroscopy, 31P-NMR spectroscopy and a unique magnesium ion-selective electrode. Alcohol Clin Exp Res 18(5): 10571068.

18. Altura BM, Altura BT (1995) Magnesium in cardiovascular biology: An important link between cardiovascular risk factors and atherogenesis Cell Mol Biol Res 41(5): 347-359.

19. Altura BM, Altura BT (1995) Magnesium in cardiovascular biology. Sci Am Sci \& Med 2: 28-37.

20. Mauskop A, Altura BT, Cracco RQ Altura BM (1995) Intravenous magnesium sulfate relieves migraine attacks in patients with low serum ionized magnesium levels: a pilot study. Clin Sci 89(6): 633-636.

21. Fredman H, Pross S, Klein TW (2006) Addictive drugs and their relationship with infectious diseases. FEMS Immunol Med Microbiol 47(3): 330-342.

22. Altura BM, Altura BT (1996) Role of magnesium in Patho-physiological processes and the clinical utility of magnesium ion-selective electrodes. Scand J Clin Lab Invest 224: 211-234.

23. Fogh-Andersen N, Altura BM, Altura BT, Sigaard-Andersen O (1996) Changes in plasma ionized calcium and magnesium in blood donors after donation of $450 \mathrm{ml}$ blood: Effects of hemodilution and Donnan equilibrium. Scand J Clin Lab Invest 56: 246-250.

24. Memon ZS, Altura BT, Benjamin JL, Cracco RQ, Altura BM (1995) Predictive value of serum ionized but not total magnesium levels in head injuries. Scand J Clin Lab Invest 55(8): 671-677.

25. Altura BT, Memon ZS, Zhang A, Cheng TP-0, Altura BM (1997) Low levels of serum ionized magnesium are found in patients early after stroke which result in rapid elevation in cytosolic free calcium and spasm in cerebral vascular muscle cells. Neurosci Lett 230(1): 37-40.

26. Resnick LM, Bardicef O, AlturaBT, Alderman MH, Altura BM (1997) Serum ionized magnesium: relation to blood pressure and racial factors. Am J Hypertension 10(12 Pt 1): 1420-1424.

27. Djurhuus S, Klitgaard NA, Pedersen KK, Ballaber O, Altura BM, et al. Magnesium reduces insulin-stimulated glucose uptake and serum lipid concentrations in type1 diabetes. Metabolism 50(12): 1409-1417.

28. Altura BM, Altura BT (1999) Association of alcohol in brain injury and serum levels of ionized magnesium: A review of recent findings and mechanisms of action. Alcohol 19(2): 119-130.
29. Kimura T, Yasue H, Sakaino N, Rokutanda M, Jougasaki M. et al. (1989) Effects of magnesium on the tone of isolated human coronary arteries. Circulation 79: 1118-1124.

30. Goto K, Yasue H, Okumura K, Matsuyama K, Kugiyama K, et al. (190) Magnesium deficiency detected by intravenous loading test in variant angina pectoris. Am J Cardiol 65(11): 709-712.

31. Simko K, Lee JD, Shinizu H, Ueda T, Nakamura T (1996) Relation between severity of magnesium deficiency and frequency of anginal attacks in men with variant angina. J Am Coll Cardiol 28(4): 897-902.

32. Simko F (1994) Pathophysiological aspects of the protective effect of magnesium in myocardial infarction. Acta Med Hung 50(1-2): 56-64.

33. Sueda S, Fukuda H, Watanabe K, Ohtani T, Uraoka T, et al. (2001) Magnesium deficiency in patients with recent myocardial infarction and provoked coronary spasm. Jap Circ J 66(7): 643-648.

34. Minato N, Katayama Y, Sakaguchi M, Itoh M (2006) Perioperative artery spasm in off-pump coronary bypass grafting and its possible relation with perioperative hypomagnesemia. Ann Thorac Cardiovasc Surg 12(1): 32-36.

35. Altura BM, Li W, Zhang A, Shah NC, Shah GJ, et al. (2016) Sudden cardiac death in infants, children and young adults: possible roles of dietary magnesium intake and generation of platelet-activating factor in coronary arteries.J Heart Health 2(2).

36. Altura BM, Li W, Zhang A, Zheng T, Yang Z-W, et al. (2016) Expression of $\mathrm{PAF}$ is induced by low extracellular $\mathrm{Mg} 2+$ in aortic, cerebral and piglet coronary arterial vascular smooth muscle cells; cross-talk with ceramide production, DNA, nuclear factor-kB and proto-oncogenes: possible links to inflammation, atherogenesis, hypertension, sudden cardiac death in children and infants and aging: hypothesis, review and viewpoint. Int J Cardiol and Res 3: 47-67.

37. Altura BM, Shah NC, Shah GJ, Zhang A, Li W, et al. (2012) Short-term magnesium deficiency upregulates ceramide synthase in cardiovascular tissues and cells: cross-talk among cytokines, Mg2+, NF-kB and de novo ceramide. Am J Physiol Heart Circ Physiol 302(1): H319-H332.

38. Altura BM, Shah NC, Shah GJ, Zhang A, Li W, et al. (2014) Short-term $\mathrm{Mg}$ deficiency upregulates protein kinase $\mathrm{C}$ isoforms in cardiovascular tissues and cells: relation to NF-kB, cytokines, ceramide salvage sphingolipid pathway and PKC-zeta: hypothesis and review. Int J Clin Exp Med 7(1): 1-21.

39. Altura BM, Altura BT (1984) Magnesium, electrolyte transport and coronary vascular tone. Drugs 28(1): 120-142.

40. Wu F, Altura BT, Gao J, Barbour RL, Altura BM, et al. (1994) Ferrylmyoglobin formation induced by acute magnesium deficiency in perfused rat heart causes cardiac failure. Biochim Biophys Acta 1225(2): 158-164.

41. Altura BM, Altura BT (1996) Magnesium as an extracellular signal in cardiovascular pathobiology. J Jap Soc Magnesium Res 15: 17-32.

42. Altura BM, Gebrewold A, Zhang A, Altura BT (2003) Low extracellular magnesium induces lipid peroxidation and activation of nuclear factor$\mathrm{kB}$ in canine vascular smooth muscle: possible relation to traumatic brain injury and strokes. Neurosci Lett 341(3): 189-192.

43. Altura BM, Altura BT (2007) Magnesium: forgotten mineral in cardiovascular biology and angiogenesis. New Perspectives in Magnesium Research pp 239-260

44. Altura BM, Shah NC, Jiang X-C, Li Z, Perez-Albela JL, et al. (2009) Shortterm magnesium deficiency results in decreased levels of serum sphingomyelin, lipid peroxidation, and apoptosis. Am J Physiol Heart Circ Physiol 297(1): H86-H92.

45. Shah NC, Liu JP, Iqbal J, Hussain M, Jiang X-C, Altura BT, et al (2011) $\mathrm{Mg}$ deficiency results in modulation of serum lipids, glutathione, and NO synthase isozyme activation in cardiovascular tissues: relevance to 
synthesis of ceramide, serum Mg and atherogenesis. Int J Clin Exp Med 4(2): 103-118.

46. Shah NC, Shah GJ, Li Z, Jiang X-C, Altura BT, et al. (2014) Short-term magnesium deficiency downregulates telomerase, upregulates neutralsphingomyelinase and induces DNA damage in cardiovascular tissues: relevance to atherogenesis, cardiovascular diseases and aging. Int J Clin Exp Med 7(3): 497-514.

47. Altura BM, Shah NC, Shah GJ, Altura BT (2016) Genotoxic effects of magnesium deficiency in the cardiovascular system and their relationship to cardiovascular diseases and atherogenesis. J Cardiovasc Dis \& Diagnosis S1(1).

48. Altura BM, Shah NC, Shah GJ, Altura BT (2018) Magnesium deficiency, sphingolipids, and telomerase: Relevance to atherogenesis, cardiovascular diseases, and aging. In: Handbook of Famine, Starvation, and Nutrient Deprivation. Springer, Berlin.

49. Sierra LM, Gaivao I (2014) Genotoxicity and DNA Repair. New York.

50. Thakore PI, Black JR, Hilton IB, Gersbach CA (2016) Editing the epigenome: technologies for programmable transcription and epigenetic modulation. Nature Meth 13:127-137.
51. Altura BM, Shah NC, Shah GJ, Altura BT (2017) Why do chemotherapeutic drugs and radiation induce cardiomyopathy and cardiac failure in cancer patients: Is this a consequence of unrecognized hypomagnesemia and release of ceramides and platelet-activating factor? SciFed J Emerg Med 1(1): 1000001.

52. Florentin M, Elisaf MS (2012) Proton pump inhibitor-induced hypomagnesemia: A new challenge. World J Nephrol 1(6): 151-154.

53. Altura BM (2018) Potential role of a recently discovered biologic, HDFx, in prevention pf deadly communicable diseases brought to Western societies: A wake-up call. Timely Topics in Clinical Immunol 2(1): 6-10.

54. Altura BM (2018) Deadly communicable diseases and "superbugs: brought to Western societies could exacerbate cardiovascular disease worldwide and why a newly discovered biologic may ameliorate these challenges: A lurking real danger and solution. EC Pharmacol and Toxicol 6(9): 821-828. 